tracing it through. I found that although there was usually a good local fit on the few streams shown, it was not possible to get a satisfactory general fit, and consequently in areas away from the streams there was some uncertainty about the positions of boundaries.

I have also noticed instances of maps which lack a graphic scale and are incorrectly stated to be so many inches to a mile; this was the scale of the original which was reduced when the block was made, and there is no direct indication of the scale of the printed map, which has to be worked out by comparison with an ordnance map.

These have all come to my notice within the past few months, although the maps themselves range over many years. In every case much, if not all, of the difficulty of using them would have disappeared had there been a national grid in existence and had it been accurately incorporated in the original map.

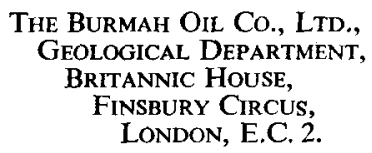

P. Evans.

\title{
YOUNGER TECTONICS AND EROSION IN WESTERN AUSTRALIA
}

SiR,--In a recent discussion in this Magazine, which has only now come to hand, ${ }^{1} \mathrm{C}$. A. Cotton postulates that the tempo of denudation in Western Australia during the Pliocene and Pleistocene could not possibly have been rapid enough to allow the levelling down of a strong relief newly created by folding and faulting of late Miocene or Pliocene age. He suggests that the tectonic movements in the North-West Basin to which I have ascribed such an age must have taken place rather earlier, though he does not say when. He finds support for these conclusions in certain features of the geology of Victoria and New South Wales.

Unfortunately, however, these theoretical deductions are contradicted by field evidence, and I also fail to see the relevance of geological observations in south-eastern Australia for the interpretation of the geological history of remote parts of Western Australia. Incidentally, the south-east corner of Australia is a good deal nearer to New Zealand than to the North-West Basin of Western Australia. Professor Cotton has opened a discussion on a most interesting subject and I regret more than ever that I found it impossible to deal more fully with the

${ }^{1}$ C. A. Cotton, Query as to the Tempo of Denudation in Australia. Geol. Mag., lxxxv, 1948, 54-6. 
physiography, structural history, or even palaeogeography of Western Australia in a publication which, as its title suggests, had stratigraphy as its main subject. ${ }^{1}$

After my second visit to the North-West Basin in 1939, I was much impressed by the amount of faulting and folding $I$ had seen and found it hard to believe that all this could have happened at once. So I wrote ${ }^{2}$ as follows : ". . . the present structures must be due to at least two, probably three, periods of crustal activity in this part of Western Australia." But then at that time we knew a lot less about the North-West Basin than we do now.

In dealing with tectonic movements in this area one has to distinguish between two problems; (1) the relationships between the Permian and the Mesozoic, and the Mesozoic and Tertiary rocks, and (2) the younger movements.

Little is known about the Permian-Mesozoic contact, which nearly everywhere is a faulted one. Raggatt ${ }^{3}$ found evidence of broad warping of the Permian rocks before the deposition of the Cretaceous, with angular unconformities possibly amounting in places to about $10^{\circ}$. In other places no such unconformities exist. No further investigations into these tectonic relationships have as yet been made. Some years ago Jurassic was discovered in a small fault block, ${ }^{4}$ but its relationships to younger and older beds are unknown. On the whole, Raggatt's picture of broad post-Permian undulations is no doubt correct. These movements determine the nature of the Permian-Mesozoic contact, but they have little influence on the present surface distribution of the rocks. The latter is entirely controlled by much younger folds and faults, all of which belong to one tectonic phase ; in other words, we are concerned with Bruchfaltung. The western half of the basin is a down-faulted area of weakly folded Cretaceous and Tertiary rocks which are thrown into a number of broad anticlines and synclines. Where the anticlines are built of resistant rocks they form low ranges, as in the North-West Cape Range, which is 1,200 feet high. Elsewhere the soft cores may be eroded away or even the flanks completely levelled down, as on the east side of the Cardabia anticline. The Cretaceous-Permian boundary fault in the Minilya River area is normal and west-dipping with the Cretaceous greensands in places occupying a vertical position.

1 C. Teichert, Stratigraphy of Western Australia. Bull. Amer. Assoc. Petrol. Geol., xxxi, 1947, 1-70, and Journ. Proc. Roy. Soc. N.S.W., Ixxx, 1947, 81-142.

${ }^{2}$ C. Teichert, Recent Research Work in the Permian of Western Australia. Aust. Journ. Sci., ii, 1939, 7.

${ }^{3}$ H. G. Raggatt, Geology of North-West Basin, Western Australia . . . Journ. Proc. Roy. Soc. N.S.W., 1xx, 1936, 100-174.

4 C. Teichert, Marine Jurassic in the North-West Basin of Western Australia. Journ. Rov. Soc. West. Aust., xxvi, 1940, 17-25. 
The Permian strata which occupy the eastern half of the basin are strongly dissected by antithetically east-dipping faults and have been folded locally in varying degrees of intensity. Individual fault blocks are commonly tilted $20-25^{\circ}$, but higher dips occur near the faults. Between the Cretaceous-Permian boundary fault and the first antithetic east-dipping fault to the east the beds are strongly folded into synclines. Strong faulting near the eastern margin of the basin has already been described by Raggatt in 1936. Faults with throws between 1,000 and 2,000 feet are quite numerous in this area.

That all this folding and faulting dates back to one, relatively young geological period, was already recognized by Raggatt who wrote ${ }^{1}$ that "folding took place on a large scale in the late Miocene or Pliocene."

To say, as I did in 1947, that the area has since undergone " almost perfect planation" was a slight overstatement. The present features of the faulted terrain depend of course very much on the hardness of the rocks. I could lead Professor Cotton across 2,000-ft. faults of which not the slightest trace can be detected in the present physiography. In the Minilya River area, for example, the greensands and shales on both sides of the fault separating the Permian from the Cretaceous-Tertiary and also many fault blocks close to this fault, have been completely planed down. Where hard sandstones and limestones are affected fault scarps are formed which may rise 300 to $400 \mathrm{ft}$., in places even higher, above the general level of the plains. This is particularly so near the eastern margin of the basin.

The youngest rocks affected by these movements are Miocene, perhaps middle Miocene, although the possibility of the presence of somewhat younger beds cannot be ruled out.

In the coastal belt, between Carnarvon and North-West Cape, we seem to have a more or less conformable Cretaceous-Tertiary sequence which includes rocks of Eocene, Oligocene, and Miocene age. Miocene strata occur also 110 miles inland in the Kennedy Range ${ }^{2}$, but their stratigraphical relationships are as yet unknown. Most probably these rocks are preserved here as erosion remnants in fault blocks at $1,000-1,200$ feet above sea-level.

The earliest date for the folding and faulting of the Permian as well as younger rocks is the late Miocene ; more probably the movements took place during the Pliocene. To disregard field evidence would be a serious error indeed. If Professor Cotton sees "vast implications" I suggest that they should be faced. Obviously conditions in the NorthWest Basin of Western Australia during the Pliocene (possibly late

1 Op. cit., p. 169.

2 C. Teichert, The genus Aturia in the Tertiary of Australia, Journ. Paleont., xviii, 1944, 73-82. 
Pliocene) and Pleistocene were such as to allow the removal by erosion of very considerable quantities of sediments and the levelling down of large tracts of country which only recently had undergone Bruchfaltung on a considerable scale, no doubt in connection with the elevation of the shield after the Miocene submergence. As observed on a recent field trip remnants of the gravels and conglomerates of this denudation period cover large areas in the Minilya River area. These deposits have been themselves subjected to more recent erosion and they are still being eroded at the present time.

Laterite is essentially restricted to the ancient shield and does not occur in the North-West Basin. Since the laterite seems to have formed on the newly-elevated shield as a subsoil (hardpan) under conditions resembling those of the wet tropics, there must have been a large amount of run-off from the plateau with consequent erosion and levelling of the marginal regions.

Cotton's statement that 100,000 cubic miles of rock would have to have been removed by erosion leaves one puzzled. From the figures given in my paper-area of North-West Basin 40,000 square miles thickness of sediments increasing from less than 5,000 feet in the south to perhaps as much as 14,000 feet in the north--it is easy to calculate that about 80,000 cubic miles would be a rather optimistic estimate for the entire original sedimentary filling of the basin. Of this perhaps two-thirds or even more must still be left.

The amount of young erosion in the North-West Basin is no greater, perhaps even smaller, than contemporaneous denudation in the East Kimberley district in the north of Western Australia as also mentioned in my 1947 paper. Here, in the White Mountains near the Ord River, young Tertiary lacustrine deposits, tilted and weakly folded are now perched at the top of a range of hills, about 1,000 feet above sea-level and 600 feet above the bed of the Ord River and the level to which much of the surrounding country has been planed down.

This remarkable occurrence has been known since 1885. Hardman, Wade, and others have remarked on it and a more detailed account, already quoted in my 1947 paper, is now available. ${ }^{1}$

We may conclude then that the younger geological history of Western Australia has followed a course somewhat different from that of the eastern half of the continent-which will not surprise anyone who is familiar with both regions.

UNIVERSITY OF MELBOURNE,

C. Teichert.

14 th June, 1948.

1 R. S. Matheson and C. Teichert, Geological Reconnaissance in the Eastern Portion of the Kimberly Division, Western Australia. Rept. Dept. Mines West. Aust. for 1945, Perth, 1948. 